\title{
Isolation, Purification, and Characterization of Xylanase Produced by a New Species of Bacillus in Solid State Fermentation
}

\author{
Rajashri D. Kamble ${ }^{1}$ and Anandrao R. Jadhav ${ }^{2}$ \\ ${ }^{1}$ Department of Biotechnology Engineering, Tatyasaheb Kore Institute of Engineering \& Technology, Warananagar Panhala, \\ Kolhapur, Maharashtra, 416113, India \\ ${ }^{2}$ Department of Microbiology, K.R.P. Kanya Mahavidyalaya, Islampur, Walwa, Sangli, Maharashtra, 415414, India
}

Correspondence should be addressed to Rajashri D. Kamble, rajashri.kamble@gmail.com

Received 8 July 2011; Revised 28 September 2011; Accepted 4 October 2011

Academic Editor: Gregory M. Cook

Copyright ( 2012 R. D. Kamble and A. R. Jadhav. This is an open access article distributed under the Creative Commons Attribution License, which permits unrestricted use, distribution, and reproduction in any medium, provided the original work is properly cited.

A thermoalkalophilic new species of Bacillus, similar to Bacillus arseniciselenatis DSM 15340, produced extracellular xylanase under solid state fermentation when wheat bran is used as carbon source. The extracellular xylanase was isolated by ammonium sulfate $(80 \%)$ precipitation and purified using ion exchange chromatography. The molecular weight of xylanase was $\sim 29.8 \mathrm{kDa}$. The optimum temperature and $\mathrm{pH}$ for the enzyme activity were $50^{\circ} \mathrm{C}$ and $\mathrm{pH} 8.0$. The enzyme was active on birchwood xylan and little active on $p$-nitrophenyl xylopyranoside but not on Avicel, CMC, cellobiose, and starch, showing its absolute substrate specificity. For birchwood xylan, the enzyme gave a $\mathrm{Km} 5.26 \mathrm{mg} / \mathrm{mL}$ and $\mathrm{Vmax} 277.7 \mu \mathrm{mol} / \mathrm{min} / \mathrm{mg}$, respectively. In addition, the xylanase was also capable of producing high-quality xylo-oligosaccharides, which indicated its application potential not only in pulp biobleaching processes but also in the nutraceutical industry.

\section{Introduction}

Xylan is the most abundant noncellulosic polysaccharide present in both hardwoods and annual plants and accounts for $20-35 \%$ of the total dry weight in tropical plant biomass [1-3]. In temperate softwoods, xylans are less abundant and may comprise about $8 \%$ of the total dry weight [4]. Xylan is found mainly in the secondary cell wall and is considered to be forming an interphase between lignin and other polysaccharides. It is likely that xylan molecules covalently link with lignin phenolic residues and also interact with polysaccharides, such as pectin and glucan. In simplest forms, xylans are linear homopolymers that contain $D$-xylose monomers linked through $\beta-1,4-$ glycosyl bonds $[5,6]$. Xylanase (E.C 3.2.1.8) degrades $\beta-1,4$ xylan by cleaving $\beta-1$, 4 glycosidic linkages randomly, and the products are xylose and xylo-oligosaccharides like xylobiose [7, 8]. Xylanases are of industrial importance, which can be used in paper manufacturing to bleach paper pulp, increasing the brightness of pulp and improving the digestibility of animal feed and for clarification of fruit juices. Applications of xylanase avoid the use of chemicals that are expensive and cause pollution [9]. Microorganisms are the rich sources of xylanases, produced by diverse genera and species of bacteria, actinomycetes, and fungi. Several species of Bacillus and filamentous fungi secrete high amounts of extracellular xylanases [10]. Xylanase secretion often associates with low or high amount of cellulases. To use xylanase for pulp treatment, it is preferable to use cellulose-free xylanases, since the cellulase may adversely affect the quality of the paper pulp [11-15]. The most practical approach is the screening for naturally occurring microbial strains capable of secreting cellulose-free $x y-$ lanases under optimized fermentation conditions. To use xylanase prominently in bleaching process it should be stable at high temperature and alkaline $\mathrm{pH}[16,17]$.

Industrial production of enzymes on large scale is associated mainly with substrate. The use of agriculture residues as low-cost substrates for the production of industrial enzymes is a significant way to reduce production cost. The technique of fermentation using solid state substrate has the great advantage over submerged fermentation due to absence or near absence of aqueous phase that provides natural habitat 
for growth of microorganisms, economy of the space, simplicity of the media, no complex machinery, equipments and control systems, greater compactness of the fermentation vessel owing to a lower water volume, greater product yields, reduced energy demand, lower capital and recurring expenditures in industry, easier scale-up of processes, lesser volume of solvent needed for product recovery, superior yields, absence of foam build-up, and easier control of contamination due to the low moisture level in the system $[10,18]$. In consideration with these facts the present study aims to characterize extracellular alkalothermophilic xylanase produced by Bacillus arseniciselenatis DSM 15340 when grown in solid state fermentation. To our knowledge, this is the first report describing the production of thermoalkalophilic cellulasefree xylanase by Bacillus arseniciselenatis DSM 15340. In addition, this xylanase was found to be able to degrade xylan into xylo-oligosaccharides.

\section{Materials and Methods}

2.1. Screening of Xylanolytic Strains. Soil samples were collected from coastal areas of Mandovi, Goa, India. Enrichment was done using birchwood xylan (Sigma Chemicals, Germany) as a sole source of carbon. Twenty five bacterial cultures were screened for xylanolytic ability by adding dyelabelled substrate, for example, xylan-brilliant red 3BA in xylan agar medium [19].

2.2. Phenotypic Characteristics. Prominent selected isolate was identified on the basis of morphological, cultural, biochemical properties [20] and 16S rRNA sequencing. Culture was deposited at National Centre for Cell Sciences (NCCS), Pune, India.

2.3. Phylogenic Analysis. The partial 16S rRNA sequences were retrieved on NCBI server (http://blast.ncbi.nlm.nih .gov/Blast.cgi) using BLAST tool. Top 10 similar sequences were downloaded in FASTA format. Multiple alignment of sequences and calculations of levels of sequence similarity were performed by using ClustalW2 program. A phylogenetic tree obtained was analyzed for closely related organism. The evolutionary history was inferred using the neighborjoining method [14].

2.4. Growth Conditions of Culture. The bacterial isolate was maintained in liquid medium as well as solid medium in basal salt solution (BSS) containing $0.5 \%$ xylan having $\mathrm{pH}$ 8.0 at $45^{\circ} \mathrm{C}$ and stored at $4^{\circ} \mathrm{C}$.

2.5. Xylanase Production in Solid State Fermentation (SSF). The selected strain was further tested for their abilities to produce extracellular xylanase under solid state fermentation. Wheat bran was used as the substrate. For this the strain was cultured in Erlenmeyer flasks $(250 \mathrm{~mL})$ containing $10 \mathrm{~g}$ of wheat bran moistened with $18 \mathrm{~mL}$ of the basal salt solution (BSS: substrate-to-moisture ratio $1: 1.8$ ). After $48 \mathrm{~h}$ of fermentation spent; solid substrate was removed and suspended in $50 \mathrm{mM}$ phosphate buffer ( $\mathrm{pH} 8.0$ ), vortexed thoroughly to extract the xylanase. The sample was centrifuged at $5000 \times \mathrm{g}$ for 10 minutes at $4^{\circ} \mathrm{C}$. Centrifugation will remove xylanase from substrate. Supernatant was filtered through Whatman No. 1 filter paper and the clear filtrate was used as crude xylanase preparation. Prior to centrifugation, the samples were withdrawn for determining viable number of cells by standard viable plate count technique.

2.6. Xylanase Assay. Xylanase activity was measured according to Bailey et al. [21]. A $900 \mu \mathrm{L}$ of $1 \%$ solubilised birchwood xylan solution was added with $100 \mu \mathrm{L}$ enzyme solution in a test tube. $1.5 \mathrm{~mL}$ DNS reagent was added and incubated at $50^{\circ} \mathrm{C}$ for $5 \mathrm{~min}$ in water bath [22]. The absorbance was measured at $540 \mathrm{~nm}$. The reaction was terminated at zero time in the control tubes. The standard graph was prepared using $0-500 \mu \mathrm{g}$ xylose. An autozero was set in UV-VIS spectrophotometer (Hitachi, Japan) using buffer solution. One unit of xylanase activity was defined as the amount of enzyme that liberates 1 micromole of reducing sugars equivalent to xylose per minute under the assay conditions described. Solubilised xylan was prepared by stirring birchwood xylan with $1 \mathrm{M} \mathrm{NaOH}$ for six hours at room temperature followed by centrifugation and freeze drying the supernatant after neutralising the alkali with $1 \mathrm{M}$ $\mathrm{HCl}$.

2.7. Cellulase Assay. Cellulase activity was measured according to Ghose with necessary modifications [23]. A $900 \mu \mathrm{L}$ $1 \%$ carboxy methyl cellulose solution was added with $100 \mu \mathrm{L}$ enzyme in a test tube. $1.5 \mathrm{~mL}$ DNS reagent was added and incubated at $50^{\circ} \mathrm{C}$ for $5 \mathrm{~min}$ in water bath. The absorbance was measured at $540 \mathrm{~nm}$. The reaction was terminated at zero time in control tubes. A standard graph was prepared using $0-500 \mu \mathrm{g}$ glucose. An autozero was set in spectrophotometer using buffer solution. One unit of cellulase activity was defined as the amount of enzyme that liberates 1 micromole of glucose equivalents per minute under the assay conditions.

2.8. 1,4- $\beta$-xylosidase Assay. 1,4- $\beta$-xylosidase activity was measured according to Lachke [24]. A $900 \mu \mathrm{L} p$-nitrophenyl $\beta$-xyloside ( $\rho$-NPX) solution was added with $100 \mu \mathrm{L}$ of appropriately diluted enzyme solution in a test tube. The mixture was incubated at $50^{\circ} \mathrm{C}$ for $30 \mathrm{~min}$. Then $1 \mathrm{~mL}$ of $2 \mathrm{M}$ sodium carbonate solution was added. The absorbance was measured at $410 \mathrm{~nm}$. The reaction was terminated at zero time in control tubes. One unit of 1,4- $\beta$-xylosidase activity was defined as the amount of enzyme that catalyzes the formation of 1 micromole of $\rho$-nitrophenol per minute under assay conditions.

2.9. Determination of Total Protein Content. Total soluble protein was measured according to Lowry et al. [25]. Protein concentration was determined using bovine serum albumin (BSA) as a standard. The protein content of the chromatographic eluant was measured by monitoring the optical density at $280 \mathrm{~nm}$. 
2.10. Ammonium Sulphate Precipitation. Protein precipitation by salting out technique using ammonium sulphate $\left(\mathrm{NH}_{4}\left(\mathrm{SO}_{4}\right)_{2}\right)$ was carried out with constant gentle stirring [26]. This was left overnight and the precipitate was collected by centrifugation at $10,000 \times \mathrm{g}$ for $10 \mathrm{~min}$. The precipitate obtained was dissolved in phosphate buffer (50 mM, pH 8.0) and dialyzed against the same buffer for $24 \mathrm{~h}$. Dialysis was carried out using cellulose tubing (molecular weight cut-off 13,000 kDa, Himedia LA393-10 MT).

2.11. Ion Exchange Chromatography. Dialyzed enzyme $(2 \mathrm{~mL})$ was loaded onto a anion exchange DEAE Cellulose (Sigma-Aldrich Co., USA) column. The column was packed with activated DEAE-cellulose equilibrated with $50 \mathrm{mM}$ phosphate buffer ( $\mathrm{pH} \mathrm{8.0)}$ ). The height of column was $20 \mathrm{~cm}$ with the $2.5 \mathrm{~cm}$ diameter. The protein was eluted with the 0.0 to $0.5 \mathrm{M} \mathrm{NaCl}$ gradient. The 50 fractions were collected having $5 \mathrm{~mL}$ volume of each fraction with the flow rate of $1 \mathrm{~mL} / \mathrm{min}$. All the steps were carried out at 4 to $8^{\circ} \mathrm{C}$.

2.12. Molecular Mass Determination by SDS-PAGE. SDSPAGE of partially purified xylanase was performed in a $12.5 \%$ acrylamide gel Laemmli [27]. Coomassie brilliant blue R-250 was used to stain the gel. The protein molecular weight markers used were of medium range containing $14.4 \mathrm{kDa}$ to 94.0 kDa obtained from Bangalore GeNei, India.

2.13. Substrate Specificity. Substrate specificity of the xylanase was found by using 1\% xylan, cellobiose, starch, carboxy methyl cellulose (CMC), and p-nitrophenyl xylopyranoside and Avicel as substrates.

2.14. Kinetic Parameters. Initial reaction rates using birchwood and oat spelt xylan as substrate were determined at substrate concentrations of $0.5-10 \mathrm{mg} / \mathrm{mL}$ in $50 \mathrm{mM}$ phosphate buffer ( $\mathrm{pH} 7.0)$ at $45^{\circ} \mathrm{C}$. The kinetic constants, $\mathrm{Km}$ and Vmax, were estimated using the linear regression method of Lineweaver and Burk [28].

2.15. Identification of Hydrolysis Products. To $50 \mathrm{~mL}$ of birchwood xylan suspension (1\% of birchwood xylan in $50 \mathrm{mM}$ Phosphate buffer $\mathrm{pH} 7.0$ ), $40 \mu \mathrm{g}$ of xylanase enzyme was added and incubated at $45^{\circ} \mathrm{C}$. Hydrolysis products were detected by thin layer chromatography (TLC) [29]. TLC (TLC plates, $0.25 \mathrm{~mm}$ layers of silica gel F 254, Merck, India) was performed using the mixture of $n$-butanol: ethanol: $\mathrm{H}_{2} \mathrm{O}(5: 3: 2$ by vol) as a solvent system. Compounds were detected by spraying with $50 \%$ sulphuric acid in ethanol followed by heating at $150^{\circ} \mathrm{C}$ for $5 \mathrm{~min}$. D-xylose $\left(\mathrm{X}_{1}\right)$, xylobiose $\left(\mathrm{X}_{2}\right)$, xylotriose $\left(\mathrm{X}_{3}\right)$, and xylotetraose $\left(\mathrm{X}_{4}\right)$ were applied as standard.

2.16. Effect of Temperature on Activity and Stability. The optimum temperature for maximum xylanase activity was determined by varying the reaction temperature from 30 to $80^{\circ} \mathrm{C}$. To evaluate thermal stability, $0.5 \mathrm{~mL}$ of the enzyme solution was incubated at $30-80^{\circ} \mathrm{C}$ temperatures for up to $4 \mathrm{~h}$. The

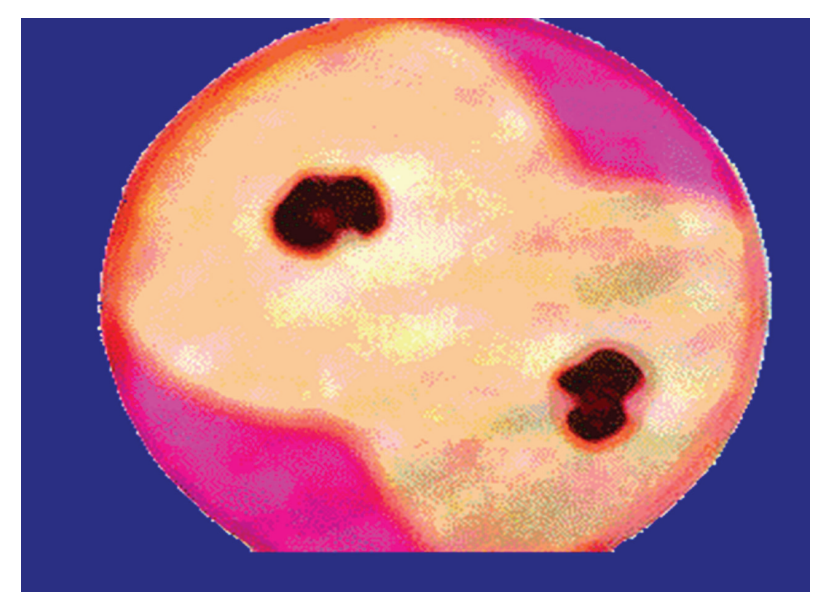

FIGURE 1: Plate showing zone of clearance around colony by isolate.

relative enzyme activity was recorded at $1 \mathrm{~h}$ interval during period of $4 \mathrm{~h}$.

2.17. Effect of $p H$ on Activity and Stability. The effect of $\mathrm{pH}$ on enzyme activity was determined by incubating xylanase at various $\mathrm{pH}$ ranging from 6.0 to 11.0 . The various buffers used were $50 \mathrm{mM}$ sodium phosphate $(\mathrm{pH} 6,7), 50 \mathrm{mM}$ Tris $\mathrm{HCl}(\mathrm{pH} 8,9), 50 \mathrm{mM}$ carbonate bicarbonate buffer $(\mathrm{pH}$ 10 ), and $50 \mathrm{mM}$ glycine- $\mathrm{NaOH}$ buffer ( $\mathrm{pH} 11)$. To evaluate the stability of the enzyme at each $\mathrm{pH}$, the purified enzyme was incubated into the respective buffer over a $\mathrm{pH}$ range of $6.0-11.0$ for up to $4 \mathrm{~h}$ at optimum temperature. The relative enzyme activity was determined at $1 \mathrm{~h}$ interval during the $4 \mathrm{~h}$ period of incubation.

\section{Results and Discussion}

3.1. Isolation and Identification of Bacteria. About 25 bacterial strains, which formed clear halos around their colonies on xylan agar plates, were picked up for further studies, isolated from soil collected at selected study site. The strain that showed $33 \mathrm{~mm}$ zone of clearance around the colony proved its xylanolytic ability (Figure 1). It was identified on the basis of various morphological and biochemical characteristics as shown in Table 1.

The isolate was confirmed as Bacillus arseniciselenatis strain DSM-15340 with partial 16S rRNA sequencing having a length of $1499 \mathrm{bp}$ nucleotide. The sequence was deposited in Gene Bank (Accession No. AJ865469). The phylogenetic relation of this isolate is as shown in Figure 2. It is closely associated with Bacillus sp. AMnr. It was also isolated from soil sample collected at coastal areas of Mandovi, Goa. Shivaji et al. isolated Bacillus arseniciselenatis DSM 15340 and Bacillus arsenicus from a bore well located in the chakdah region of West Bengal, India [30].

3.2. Xylanase Production in SSF. When the strain was grown on wheat bran for 3 days of incubation at $\mathrm{pH} 8.0$ and $45^{\circ} \mathrm{C}$, maximum xylanase production was observed, that is, 910.49 U/gram dry substance, which was absolutely free from 


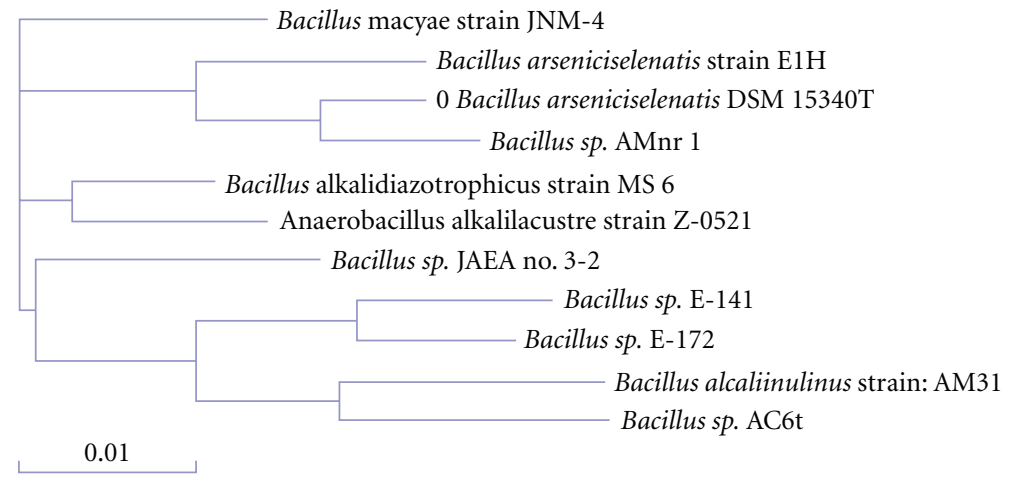

FIGURE 2: The phylogenetic tree of Bacillus arseniciselenatis DSM 15340 (designated as "0").

TABLE 1: Morphological, physiological, and biochemical characteristics of the isolate.

\begin{tabular}{|c|c|c|c|}
\hline Tests & Results & Tests & Results \\
\hline \multicolumn{2}{|c|}{ Colony morphology } & \multicolumn{2}{|c|}{ Growth on $\mathrm{NaCl}(\%)$} \\
\hline Shape & Circular & 2.0 & - \\
\hline Margin & Regular & 4.0 & - \\
\hline Elevation & Raised & 6.0 & + \\
\hline Consistency & Moist & 8.0 & + \\
\hline Color & Pale yellow & 10.0 & - \\
\hline Opacity & Opaque & Anaerobic Growth & Facultative \\
\hline Gram nature & Gram Positive & \multicolumn{2}{|c|}{ Utilization of carbohydrates } \\
\hline $\begin{array}{l}\text { Shape of the } \\
\text { cell }\end{array}$ & Long rods & Xylose & + \\
\hline Motility & $\begin{array}{l}\text { Sluggish } \\
\text { Motile }\end{array}$ & Lactose & + \\
\hline $\begin{array}{l}\text { Endospore } \\
\text { position }\end{array}$ & Central & Mannitol & - \\
\hline \multicolumn{2}{|c|}{ Growth at temperatures } & Arabinose & - \\
\hline $10^{\circ} \mathrm{C}$ & - & Sucrose & - \\
\hline $25^{\circ} \mathrm{C}$ & - & Glucose & - \\
\hline $30^{\circ} \mathrm{C}$ & + & Fructose & + \\
\hline $37^{\circ} \mathrm{C}$ & + & Melibiose & - \\
\hline $45^{\circ} \mathrm{C}$ & +++ & Starch hydrolysis & + \\
\hline $60^{\circ} \mathrm{C}$ & + & Gelatin hydrolysis & + \\
\hline $70^{\circ} \mathrm{C}$ & - & Urea hydrolysis & - \\
\hline \multicolumn{2}{|c|}{ Growth at $\mathrm{pH}$} & Esculin hydrolysis & - \\
\hline 5.0 & - & Casein hydrolysis & - \\
\hline 6.0 & - & $\begin{array}{l}\text { Tween } 20 \\
\text { hydrolysis }\end{array}$ & + \\
\hline 7.0 & + & Catalase test & + \\
\hline 8.0 & ++ & Oxidase test & + \\
\hline \multirow[t]{2}{*}{10.0} & - & Nitrate reduction & + \\
\hline & & $\mathrm{H}_{2} \mathrm{~S}$ production & - \\
\hline
\end{tabular}

+: Positive; -: Negative.

cellulase. Several workers reported the suitability of wheat bran for xylanase production in SSF [31, 32]. Commercial wheat bran consists of $30 \%$ cellulose, $27 \%$ hemicellulose, $21 \%$ lignin, and $8 \%$ ash [33]. Hence there was increase in possibility of cellulase contamination when grown on wheat bran. Haltrich et al. also reported that xylanases were always associated with cellulase [34]. From twenty selected strains, five were able to produce cellulase along with xylanase in SSF. This was due to the presence of cellulose in substrate wheat bran used in SSF.

3.3. Purification of Xylanase. The culture filtrate was precipitated by fractional $(35-80 \%)$ ammonium sulphate saturation. Proteins precipitated within this range had maximum xylanase activity and was used for purification. Xylanase was further purified by DEAE cellulose ion exchange column. The enzyme was eluted from DEAE cellulose column at a $\mathrm{NaCl}$ concentration of $0.25 \mathrm{M}$ (Figure 3). The fractions (no. 19-25) having maximum specific activity were concentrated. Xylanase was purified 3.06-fold with a specific activity of $299.25 \mathrm{U} / \mathrm{mg}$ (Table 2).

The specific activity of xylanase produced by Bacillus pumilus was previously reported as $298 \mathrm{U} / \mathrm{mg}$ by Panbangred et al. [35].

3.4. Molecular Weight Determination. The purified enzyme showed a single-protein band on SDS-PAGE. The molecular mass of denatured xylanase, estimated from the relative mobility of proteins on SDS-PAGE, was $\sim 29.8 \mathrm{kDa}$ as shown in Figure 4. The present results were supported by previous work. The enzyme from a fungus Plectosphaerella cucumerina had a molecular weight of $19 \mathrm{kDa}$ reported by Zhang et al. [36]. Xylanase produced by Bacillus sp. strain BP-23 is of $32 \mathrm{kDa}$ [37] whereas the second xylanase obtained from Bacillus firmus had a molecular weight of $45 \mathrm{kDa}$ [38].

3.5. Substrate Specificity. The action of the purified xylanase towards various substrates was studied. The enzyme was active on birchwood xylan, little active on p-nitrophenyl xylopyranoside but not on Avicel, CMC, cellobiose, and starch (Table 3). Purified xylanase was not active on Avicel, $\mathrm{CMC}$, cellobiose, and starch even when the enzyme concentration was 5 times greater than used in normal assay and incubation period of 20 minutes rather than 5 minutes. Similarly, xylanase with absolute substrate specificity was purified from Trichoderma viride by Ujiie et al. [39]. Kanda et al. 
TABLE 2: Purification steps of xylanase enzyme isolated from Bacillus arseniciselenatis DSM 15340 when grown on wheat bran.

\begin{tabular}{lcccc}
\hline Purification steps & Xylanase activity $(\mathrm{U})$ & Total protein content $(\mathrm{mg})$ & Specific activity $(\mathrm{U} / \mathrm{mg})$ & Purification fold \\
\hline Crude filtrate & 231659 & 2376 & 97.49 & 1.0 \\
$\left(\mathrm{NH}_{4}\right)_{2} \mathrm{SO}_{4}$ precipitation & 196220 & 1460 & 134.39 & 1.37 \\
DEAE sepharose FF & 96360 & 322 & 299.25 & 3.06 \\
\hline
\end{tabular}

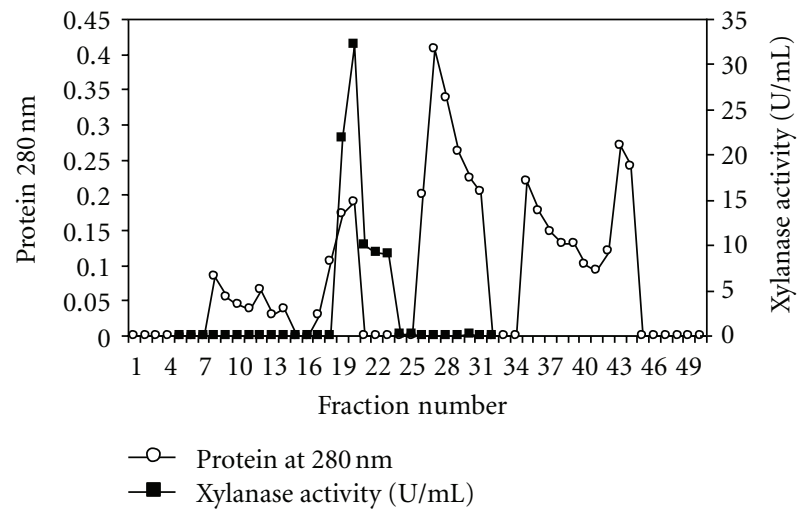

Figure 3: Elution profile of xylanase from DEAE-cellulose column chromatography.

purified two different xylanases, named xyl I and III that showed no activity towards glycans, other than xylan, such as starch, pachyman, and Avicel (microcrystalline cellulose), except for the almost one twentieth activity of xyl III toward carboxymethyl cellulose (CMC) [40].

3.6. Kinetic Parameters. The kinetic parameters $\mathrm{Km}$ and $V_{\max }$ of the enzyme were determined from LineweaverBurk double-reciprocal plots of xylanase activity at $45^{\circ} \mathrm{C}$ using various concentrations of birchwood xylan as substrate (Figure 5). The $\mathrm{Km}$ and $V_{\max }$ values of xylanase were $5.26 \mathrm{mg} / \mathrm{mL}$ and $277.7 \mu \mathrm{mol} / \mathrm{min} / \mathrm{mg}$, respectively. Wang et al. reported that $\mathrm{Km}$ and $V_{\max }$ values of xylanase isolated from Bacillus sp. NTU-06 were $3.45 \mathrm{mg} / \mathrm{mL}$ and $387.3 \mu \mathrm{mol} / \mathrm{min} / \mathrm{mg}$, respectively [41]. Bansod et al. also reported that $\mathrm{Km}$ values of xylanases lie in the range from 0.5 to $19.6 \mathrm{mg} / \mathrm{mL}$ [42]. Xylanases isolated from Aeromonas cavie $171 \mathrm{ME}-1$ and Bacillus sp. strain $41 \mathrm{~m}-1$ showed similar values of $V_{\max } 260$ to $350 \mu \mathrm{mol} / \mathrm{min} / \mathrm{mg}$ protein $[43,44]$.

3.7. Analysis of Hydrolytic Products. After $1 \mathrm{~h}$ of incubation of birchwood xylan with xylanase Bacillus arseniciselenatis DSM 15340, xylotriose and xylotetraose were the main products in the hydrolytic mixture along with little amount xylobiose. (Figure 6). The present results indicated that xylanase cleaved the substrate to liberate mainly xylooligosaccharides, but not able to act on resulting oligosaccharides to form xylose, suggesting that it is a endoxylanase.

Analysis of hydrolytic products of xylan by the xylanase of Thermoascus aurantiacus showed that xylan was degraded to various xylo-oligosaccharides without a significant accumulation of xylose [45]. Xylobiose and xylotriose were

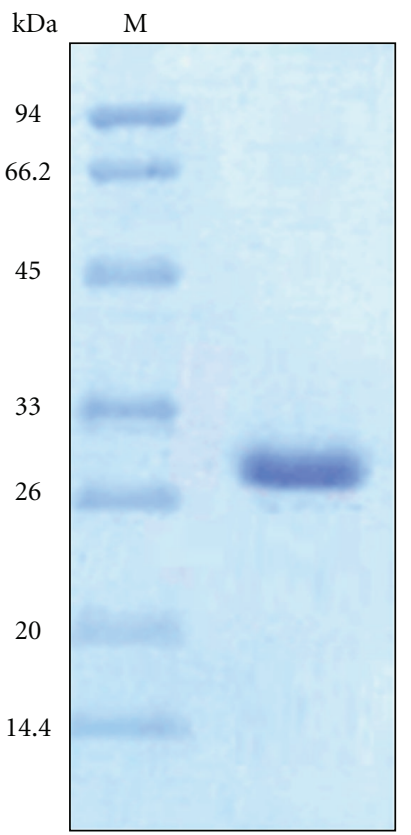

FIGURE 4: SDS-PAGE analysis of purified xylanases from Bacillus arseniciselenatis DSM 15340. Lane M: molecular markers; Lane B: Purified xylanase enzyme.

TABLE 3: Substrate specificity of purified xylanase.

\begin{tabular}{lc}
\hline Substrates & Xylanase activity (U/mg protein) \\
\hline Birchwood xylan & $291.9 \pm 0.35$ \\
Cellobiose & $0.0 \pm 0.0$ \\
Starch & $0.0 \pm 0.0$ \\
Carboxy methyl cellulose (CMC) & $0.0 \pm 0.0$ \\
p-Nitrophenyl xylopyranoside & $0.22 \pm 0.001$ \\
Avicel & $0.0 \pm 0.0$ \\
\hline
\end{tabular}

Each value represents the mean $\underline{ \pm}$ standard error values.

the main hydrolysis products when xylanase of Bacillus stearothermophilus reacted with oat spelt xylan and resulted oligosaccharides were then cleaved to form xylose by the $\beta$-xylosidase action [46]. The end products were xylobiose, xylotriose, xylotetraose, and higher oligosaccharides when xylan was hydrolyzed with endoxylanase of alkalophilic Bacillus sp. No. C-125. No xylose was found in the hydrolysis products when analysed by HPLC [47].

3.8. Effect of Temperature on Activity and Stability. For xylanase from Bacillus arseniciselenatis DSM 15340, activity 


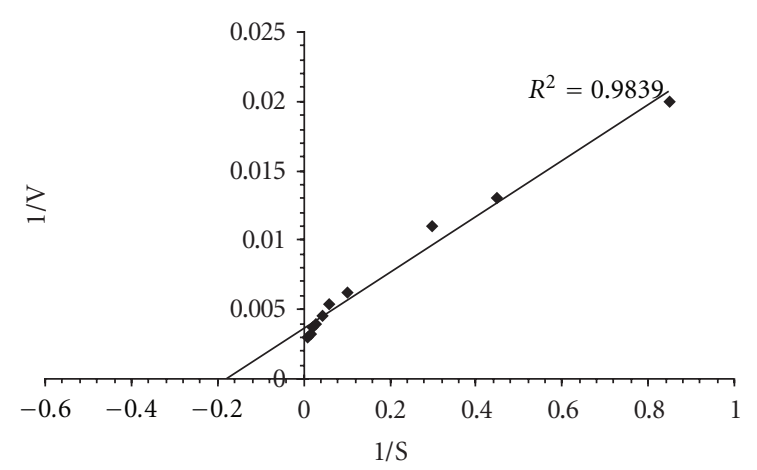

Figure 5: Double reciprocal plot for determining the $V_{\max }$ and $\mathrm{Km}$ values of xylanase Bacillus arseniciselenatis DSM 15340 when acted on Birchwood xylan.

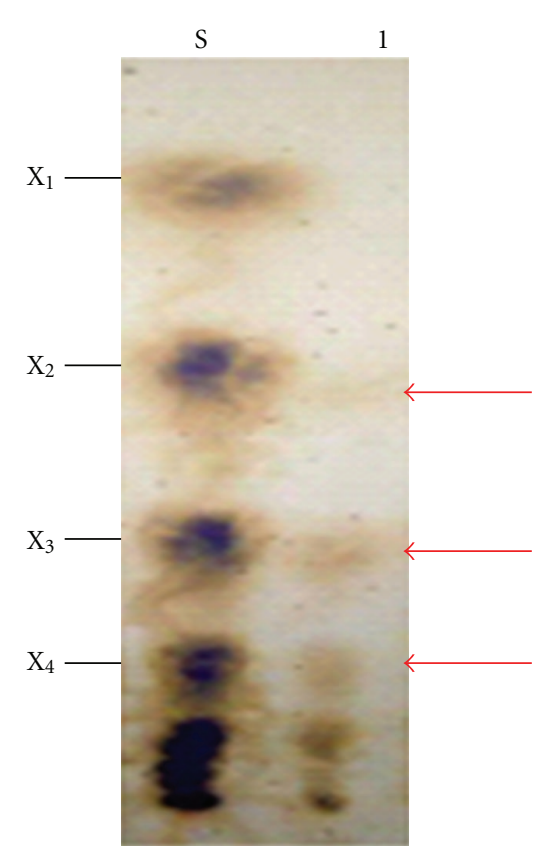

FIGURE 6: TLC analysis for hydrolysis products released from birchwood xylan by xylanase from Bacillus arseniciselenatis DSM 15340. $\mathrm{S}$ : substrate; 1 : sample; $\mathrm{X}_{1}$ : $\mathrm{D}$-xylose; $\mathrm{X}_{2}$ : xylobiose; $\mathrm{X}_{3}$ : xylotriose; $\mathrm{X}_{4}$ : xylotetraose.

was found to be gradually increased with increasing temperature and found significantly declined at $80^{\circ} \mathrm{C}$ (Figure 7). $50^{\circ} \mathrm{C}$ was found to be the most favourable for enzyme activity. Stability of the enzyme was the most important factor in studying characteristics. In case of xylanase purified from Bacillus arseniciselenatis DSM 15340, it was more stable at temperatures $30^{\circ} \mathrm{C}$ and $40^{\circ} \mathrm{C}$ for $4 \mathrm{~h}$ of incubation and retained almost $93 \%$ activity. At higher temperature values xylanase stability was gradually declined (Figure 8). Bernier et al. reported that multiple forms of xylanases were purified from Aeromonas sp. by Ohkoshi et al. and the properties of the three xylanases were well characterized $[2,48]$. It was found that these xylanases were most active at $50^{\circ} \mathrm{C}$ to $60^{\circ} \mathrm{C}$. Kang et al. purified two xylanases which gave the highest

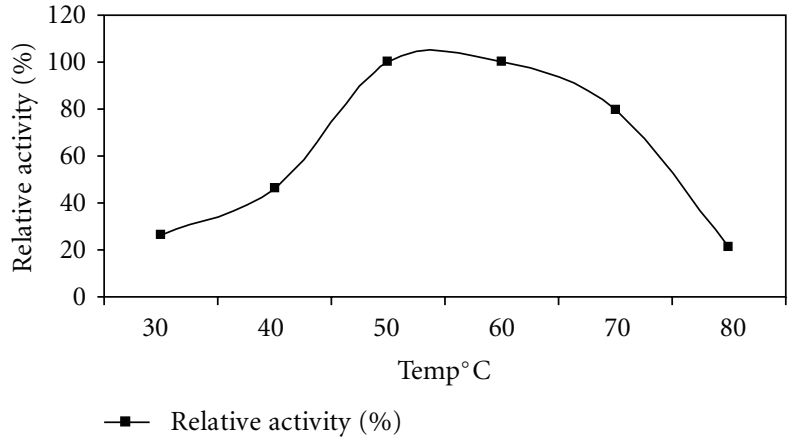

FIGURE 7: Effect of temperature on activity of xylanase from Bacillus arseniciselenatis DSM 15340.

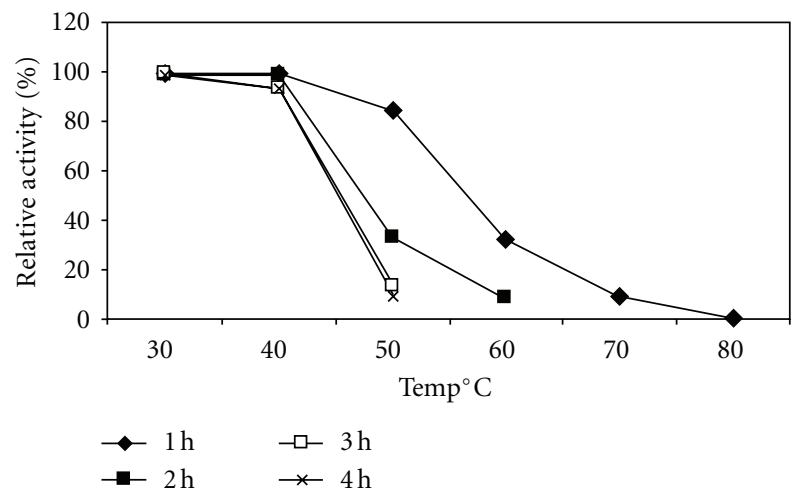

FIGURE 8: Effect of temperature on stability of xylanase from Bacillus arseniciselenatis DSM 15340.

activity at $50^{\circ} \mathrm{C}$. They showed relatively high stabilities at $50^{\circ} \mathrm{C}$ temperature [49].

3.9. Effect of $\mathrm{pH}$ on Activity and Stability. $\mathrm{pH}$ was the most important factor to characterize the enzyme. Xylanase from Bacillus arseniciselenatis DSM 15340 showed 100\% activity at $\mathrm{pH} 8.0$ (Figure 9). At higher $\mathrm{pH}$ values also, activity was $95 \%$. With respect to stability, at all tested $\mathrm{pH}$ values xylanase activity was $100 \%$ activity for $1 \mathrm{~h}$. pH 10.0 was the most favourable for stability and retained $60 \%$ activity for $4 \mathrm{~h}$ of incubation (Figure 10).

Similarly, Honda et al. purified two xylanases namely xylanases N and xylanase A from Bacillus sp. No. C-125 [47]. Among these xylanases, $\mathrm{N}$ shows maximum activity at $\mathrm{pH}$ ranging from 6.0 to 7.0 , while xylanase $\mathrm{A}$ was active at $\mathrm{pH}$ ranging from 6.0 to 10.0 and showed some activity at $\mathrm{pH}$ 12.0 also. In the present study, $100 \%$ activity was retained by Bacillus arseniciselenatis DSM 15340 xylanase for $2 \mathrm{~h}$ of incubation at $\mathrm{pH}$ 10.0. Stability at the extreme $\mathrm{pH}$ values may be due to charged amino acid residues. The enzymes stable in alkaline conditions were characterized by a decreased number of acidic residues and an increased number of arginines [50]. 


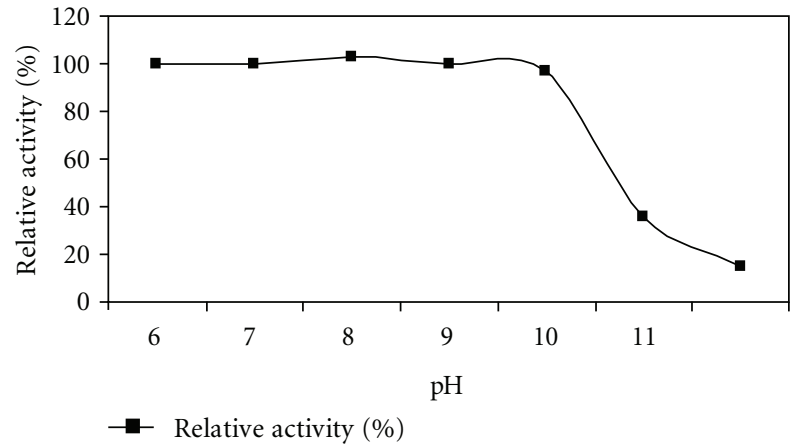

FIGURE 9: Effect of $\mathrm{pH}$ on activity of xylanase from Bacillus arseniciselenatis DSM 15340.

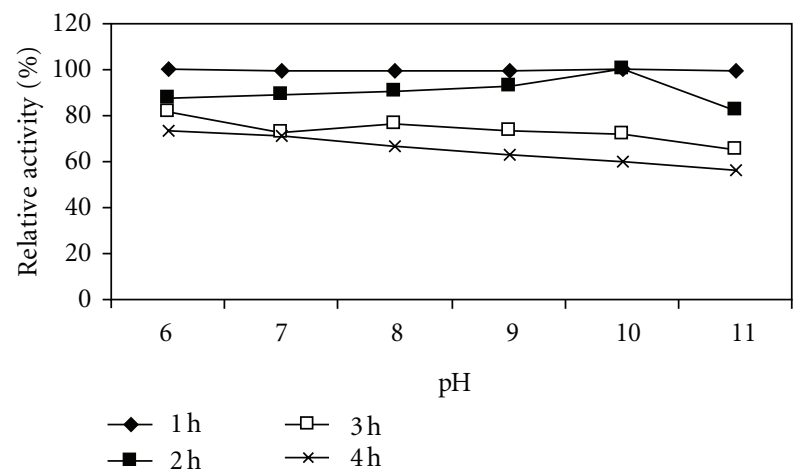

FIGURE 10: Effect of $\mathrm{pH}$ on stability of xylanase from Bacillus arseniciselenatis DSM 15340.

\section{Conclusions}

Bacillus arseniciselenatis DSM 15340 produced a thermoalkalophilic cellulose-free xylanase in higher amount when grown on solid state conditions using cheaply available agroresidual substrate wheat bran. Hence it can be used for large-scale production of xylanase using such agroresidual substrates. The purified xylanase also was capable of producing high-quality xylo-oligosaccharides, indicating its application potential not only in pulp biobleaching processes but also in the nutraceutical industry.

\section{Acknowledgment}

The authors are thankful to Dr. V. V. Kajinnii, Principal, Tatyasaheb Kore Institute of Engineering and Technology, Warananagar, India, for financial support.

\section{References}

[1] M. Bataillon, A. P. Nunes Cardinali, and F. Duchiron, "Production of xylanases from a newly isolated alkalophilic thermophilic Bacillus sp," Biotechnology Letters, vol. 20, no. 11, pp. 1067-1071, 1998.

[2] R. Bernier, M. Desrochers, L. Jurasek, and M. G. Paice, "Isolation and characterization of a xylanase from Bacillus subtilis," Applied and Environmental Microbiology, vol. 46, no. 2, pp. 511-514, 1983.
[3] G. Elegir, G. Szakacs, and T. W. Jeffries, "Purification, characterization, and substrate specificities of multiple xylanases from Streptomyces sp. strain B-12-2," Applied and Environmental Microbiology, vol. 60, no. 7, pp. 2609-2615, 1994.

[4] R. D.S. Khandeparkar and N. B. Bhosle, "Isolation, purification and characterization of the xylanase produced by Arthrobacter sp. MTCC 5214 when grown in solid-state fermentation," Enzyme and Microbial Technology, vol. 39, no. 4, pp. 732-742, 2006.

[5] Q. K. Beg, M. Kapoor, L. Mahajan, and G. S. Hoondal, "Microbial xylanases and their industrial applications: a review," Applied Microbiology and Biotechnology, vol. 56, no. 3-4, pp. 326-338, 2001.

[6] N. Kulkarni, A. Shendye, and M. Rao, "Molecular and biotechnological aspects of xylanases," FEMS Microbiology Reviews, vol. 23, no. 4, pp. 411-456, 1999.

[7] C. Tachaapaikoon, K. L. Kyu, and K. Ratanakhanokchai, "Purification of xylanase from alkaliphilic Bacillus sp. K-8 by using corn husk column," Process Biochemistry, vol. 41, no. 12, pp. 2441-2445, 2006.

[8] S. B. Chidi, B. Godana, I. Ncube, E. J. Van Rensburg, A. Cronshaw, and E. K. Abotsi, "Production, purification and characterization of celullase-free xylanase from Aspergillus terreus UL 4209," African Journal of Biotechnology, vol. 7, no. 21, pp. 3939-3948, 2008.

[9] M. E. Flores, R. Pérez, and C. Huitrón, “ $\beta$-Xylosidase and xylanase characterization and production by streptomyces sp. CH-M-1035," Letters in Applied Microbiology, vol. 24, no. 5, pp. 410-416, 1997.

[10] A. Archana and T. Satyanarayana, "Xylanase production by thermophilic Bacillus licheniformis A99 in solid-state fermentation," Enzyme and Microbial Technology, vol. 21, no. 1, pp. 12-17, 1997.

[11] A. Gessesse and G. Mamo, "Purification and characterization of an alkaline xylanase from alkalophilic Micrococcus sp. AR135," Journal of Industrial Microbiology and Biotechnology, vol. 20, pp. 210-214, 1998.

[12] S. Nakamura, K. Wakabayashi, R. Nakai, R. Aono, and K. Horikoshi, "Purification and some properties of an alkaline xylanase from alkaliphilic Bacillus sp. strain 41M-1," Applied and Environmental Microbiology, vol. 59, no. 7, pp. 2311-2316, 1993.

[13] S. Ninawe, M. Kapoor, and R. C. Kuhad, "Purification and characterization of extracellular xylanase from Streptomyces cyaneus SN32," Bioresource Technology, vol. 99, no. 5, pp. 12521258, 2008.

[14] N. Saitou and M. Nei, "The neighbor-joining method: a new method for reconstructing phylogenetic trees," Molecular Biology and Evolution, vol. 4, no. 4, pp. 406-425, 1987.

[15] D. Shallom and Y. Shoham, "Microbial hemicellulases," Current Opinion in Microbiology, vol. 6, no. 3, pp. 219-228, 2003.

[16] M. C. Srinivasan and M. V. Rele, "Microbial xylanases for paper industry," Current Science, vol. 77, no. 1, pp. 137-142, 1999.

[17] L. Viikari, A. Kantelinen, K. Poutanen, and M. Ranua, "Characterization of pulps treated with hemicellulolytic enzymes prior to bleaching," in Biotechnology in Pulp and Paper Manufacture, T. K. Kirk and H. M. Chang, Eds., pp. 145-151, Butterworth-Heinemann, Stoneham, Mass, USA, 1990.

[18] M. Ayyachamy and T. M. Vatsala, "Production and partial characterization of cellulase free xylanase by Bacillus subtilis C 01 using agriresidues and its application in biobleaching of nonwoody plant pulps," Letters in Applied Microbiology, vol. 45, no. 5, pp. 467-472, 2007. 
[19] L. N. Ten, W. T. Im, M. K. Kim, M. S. Kang, and S. T. Lee, "Development of a plate technique for screening of polysaccharide-degrading microorganisms by using a mixture of insoluble chromogenic substrates," Journal of Microbiological Methods, vol. 56, no. 3, pp. 375-382, 2004.

[20] P. H. A. Sneath, "Endospore forming Gram positive rods and cocci," in Bergey's Manual of Systematic Bacteriology, W. M. Hensyl, Ed., Williams \& Wilkins, Philadelphia, Pa, USA, 9th edition, 1994.

[21] M. J. Bailey, P. Biely, and K. Poutanen, "Interlaboratory testing of methods for assay of xylanase activity," Journal of Biotechnology, vol. 23, no. 3, pp. 257-270, 1992.

[22] G. L. Miller, "Use of dinitrosalicylic acid reagent for determination of reducing sugar," Analytical Chemistry, vol. 31, no. 3, pp. 426-428, 1959.

[23] T. K. Ghose, "Measurement of cellulase activities," Pure and Applied Chemistry, vol. 59, pp. 257-268, 1987.

[24] A. H. Lachke, "1,4- $\beta$-d-Xylan xylohydrolase of Sclerotium rolfsii," Methods in Enzymology, vol. 160, no. C, pp. 679-684, 1988.

[25] O. H. Lowry, N. J. Rosebrough, A. L. Farr, and R. J. Randall, "Protein measurement with the Folin phenol reagent," The Journal of Biological Chemistry, vol. 193, no. 1, pp. 265-275, 1951.

[26] V. Jagannathan, K. Singh, and M. Damodaran, "Carbohydrate metabolism in citric acid fermentation. 4. Purification and properties of aldolase from Aspergillus niger," The Biochemical Journal, vol. 63, no. 1, pp. 94-105, 1956.

[27] U. K. Laemmli, "Cleavage of structural proteins during the assembly of the head of bacteriophage T4," Nature, vol. 227, no. 5259 , pp. 680-685, 1970.

[28] H. Lineweaver and D. Burk, "The determination of enzyme dissociation constants," Journal of the American Chemical Society, vol. 56, no. 3, pp. 658-666, 1934.

[29] W. E. Trevelyan, D. P. Procter, and J. S. Harrison, "Detection of sugars on paper chromatograms," Nature, vol. 166, no. 4219, pp. 444-445, 1950.

[30] S. Shivaji, K. Suresh, P. Chaturvedi, S. Dube, and S. Sengupta, "Bacillus arsenicus sp. nov., an arsenic-resistant bacterium isolated from a siderite concretion in West Bengal, India," International Journal of Systematic and Evolutionary Microbiology, vol. 55, no. 3, pp. 1123-1127, 2005.

[31] J. X. Heck, L. H. D. B. Soares, P. F. Hertz, and M. A. Z. Ayub, "Purification and properties of a xylanase produced by Bacillus circulans BL53 on solid-state cultivation," Biochemical Engineering Journal, vol. 32, no. 3, pp. 179-184, 2006.

[32] K. Malarvizhi, K. Murugesan, and P. T. Kalaichelvan, "Xylanase production by Ganoderma lucidum on liquid and solid state fermentation," Indian Journal of Experimental Biology, vol. 41, no. 6, pp. 620-626, 2003.

[33] P. V. Gawande and M. Y. Kamat, "Production of Aspergillus xylanase by lignocellulosic waste fermentation and its application," Journal of Applied Microbiology, vol. 87, no. 4, pp. 511$519,1999$.

[34] D. Haltrich, B. Nidetzky, K. D. Kulbe, W. Steiner, and S. Župančič, "Production of fungal xylanases," Bioresource Technology, vol. 58, no. 2, pp. 137-161, 1996.

[35] W. Panbangred, A. Shinmyo, S. Kinoshita, and H. Okada, "Purification and properties of endoxylanase produced by Bacillus pumilus," Agricultural and Biological Chemistry, vol. 47, no. 5, pp. 957-963, 1983.

[36] G. M. Zhang, J. Huang, G. R. Huang, L. X. Ma, and X. E. Zhang, "Molecular cloning and heterologous expression of a new xylanase gene from Plectosphaerella cucumerina," Applied
Microbiology and Biotechnology, vol. 74, no. 2, pp. 339-346, 2007.

[37] A. Blanco, T. Vidal, J. F. Colom, and F. I. J. Pastor, "Purification and properties of xylanase A from alkali-tolerant Bacillus sp. strain BP-23," Applied and Environmental Microbiology, vol. 61, no. 12, pp. 4468-4470, 1995.

[38] M. J. Tseng, M. N. Yap, K. Ratanakhanokchai, K. L. Kyu, and S. T. Chen, "Purification and characterization of two cellulase free xylanases from an alkaliphilic Bacillus firmus," Enzyme and Microbial Technology, vol. 30, no. 5, pp. 590-595, 2002.

[39] M. Ujiie, C. Roy, and M. Yaguchi, "Low-molecular-weight xylanase from Trichoderma viride," Applied and Environmental Microbiology, vol. 57, no. 6, pp. 1860-1862, 1991.

[40] T. Kanda, Y. Amano, and K. Nisizawa, "Purification and properties of two endo-1,4- $\beta$-xylanases from Irpex lacteus (Polyporus tulipiferae)," Journal of Biochemistry, vol. 98, no. 6, pp. 1545-1554, 1985.

[41] C. Y. Wang, H. Chan, H. T. Lin, and Y. T. Shyu, "Production, purification and characterisation of a novel halostable xylanase from Bacillus sp. NTU-06," Annals of Applied Biology, vol. 156, no. 2, pp. 187-197, 2010.

[42] S. M. Bansod, M. Datta-Choudhary, M. C. Shrinivasan, and M. V. Rele, "Xylanase active at high $\mathrm{pH}$ from an alkalitolerant Cephalosporium species," Biotechnology Letters, vol. 15, pp. 965-970, 1993.

[43] B. K. Kubata, T. Suzuki, H. Horitsu, K. Kawal, and K. Takamizawa, "Purification and characterization of Aeromonas caviae ME-1 xylanases $\mathrm{V}$, which produces exclusively xylobiose from xylan," Applied and Environmental Microbiology, vol. 60, no. 2, pp. 531-535, 1994.

[44] S. Nakamura, Y. Ishiguro, R. Nakai, K. Wakabayashi, R. Aono, and K. Horikoshi, "Purification and characterization of a thermophilic alkaline xylanase from thermoalkaliphilic Bacillus sp. strain TAR-1," Journal of Molecular Catalysis B, vol. 1, no. 1, pp. 7-15, 1995.

[45] L. U. L. Tan, P. Mayers, and J. N. Saddler, "Purification and characterization of a thermostable xylanase from a thermophilic fungus Thermoascus aurantiacus," Canadian Journal of Microbiology, vol. 33, no. 8, pp. 689-692, 1987.

[46] T. Nanmori, T. Watanabe, R. Shinke, A. Kohno, and Y. Kawamura, "Purification and properties of thermostable xylanase and $\beta$-xylosidase produced by a newly isolated Bacillus stearothermophilus strain," Journal of Bacteriology, vol. 172, no. 12, pp. 6669-6672, 1990.

[47] H. Honda, T. Kudo, Y. Ikura, and K. Horikoshi, "Two types of xylanases of alkalophilic Bacillus sp. No. C-125," Canadian Journal of Microbiology, vol. 31, no. 6, pp. 538-542, 1985.

[48] A. Ohkoshi, T. Kudo, T. Mase, and K. Horikoshi, "Purification of three types of xylanases from an alkaliphilic Aeromonas sp," Agricultural and Biological Chemistry, vol. 49, no. 10, pp. 30373038, 1985.

[49] M. K. Kang, P. J. Maeng, and Y. H. Rhee, "Purification and characterization of two xylanases from alkaliphilic Cephalosporium sp. strain RYM-202," Applied and Environmental Microbiology, vol. 62, no. 9, pp. 3480-3482, 1996.

[50] N. Hakulinen, O. Turunen, J. Jänis, M. Leisola, and J. Rouvinen, "Three-dimensional structures of thermophilic $\beta$-1,4xylanases from Chaetomium thermophilum and Nonomuraea flexuosa: comparison of twelve xylanases in relation to their thermal stability," European Journal of Biochemistry, vol. 270, no. 7, pp. 1399-1412, 2003. 

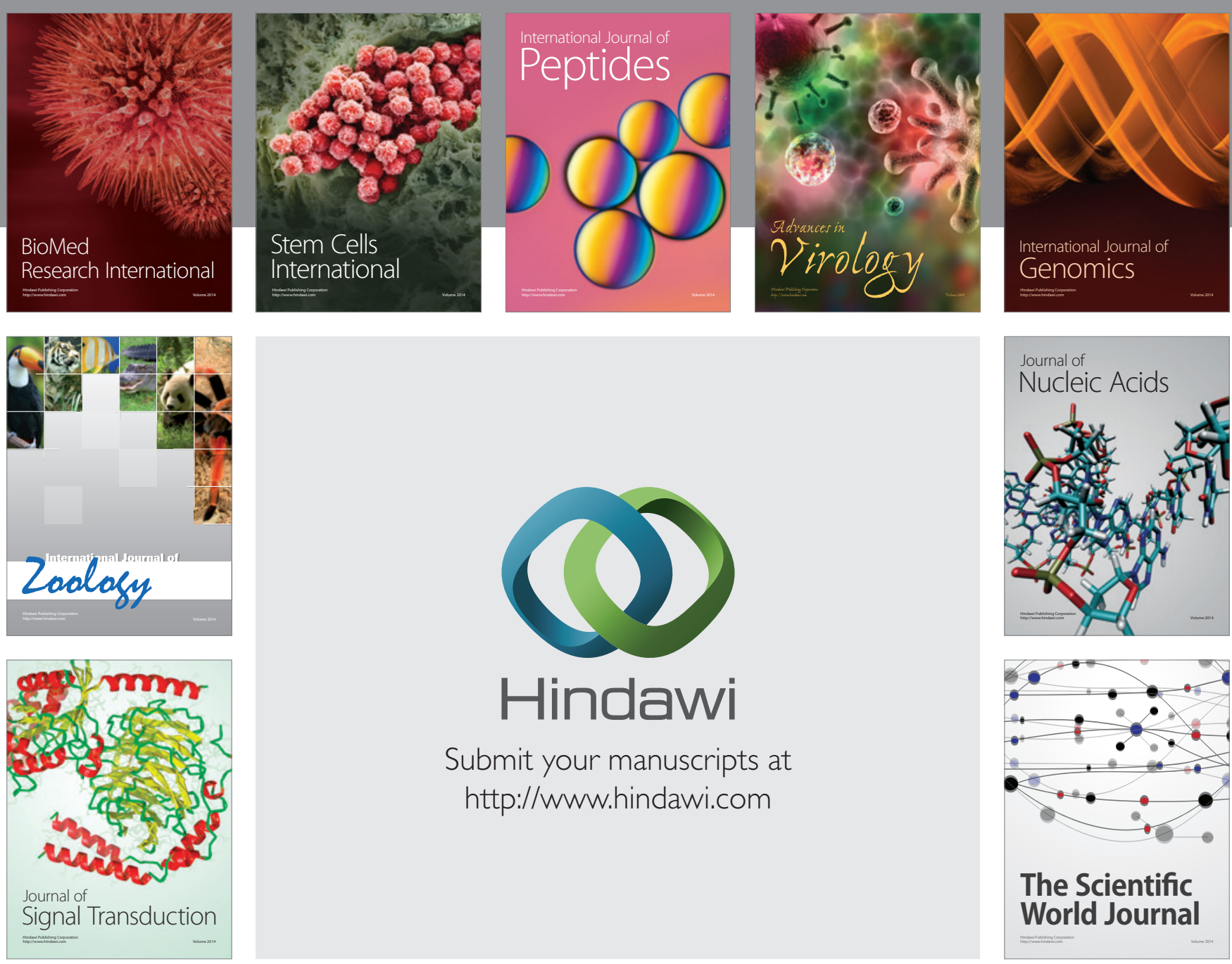

Submit your manuscripts at

http://www.hindawi.com
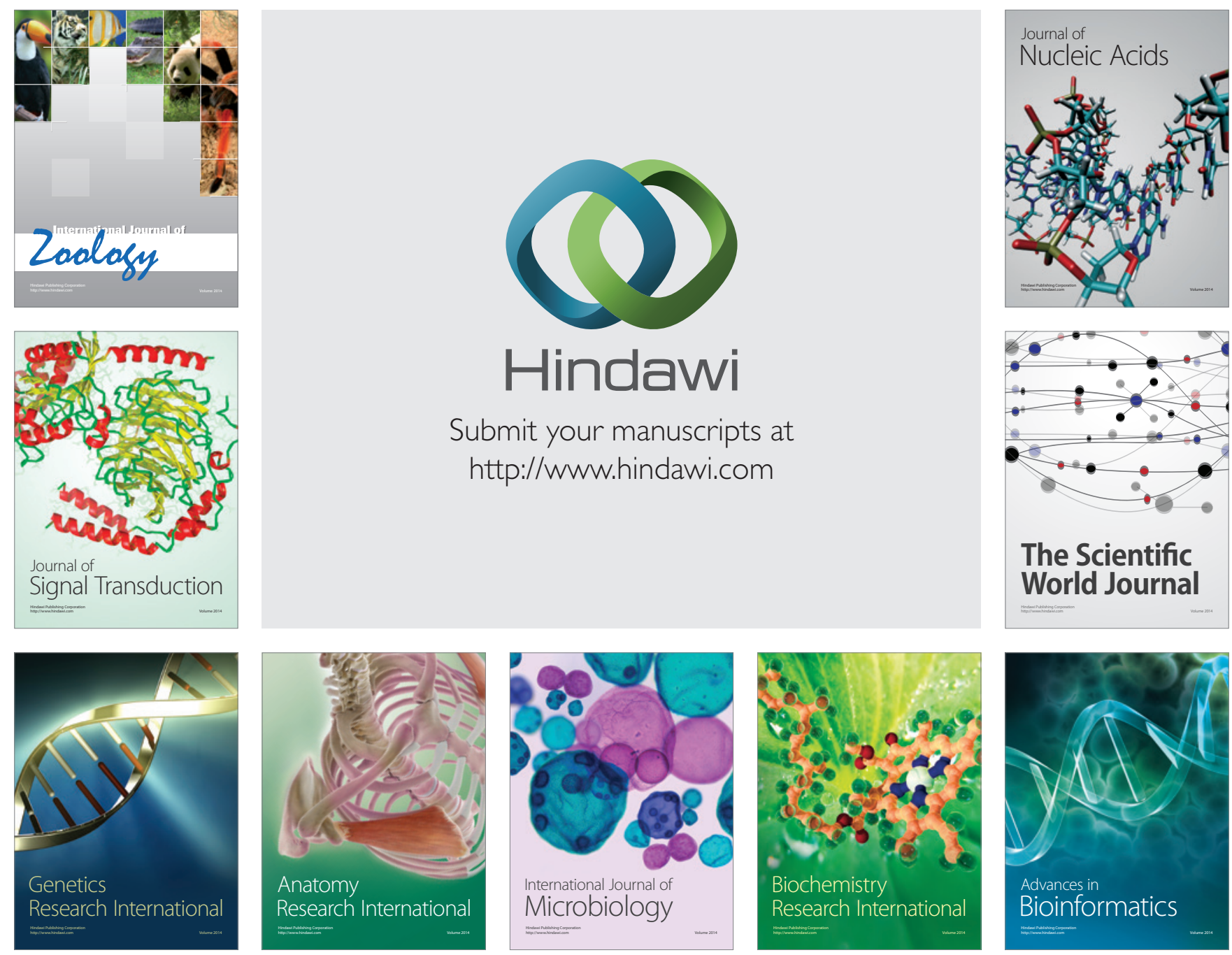

The Scientific World Journal
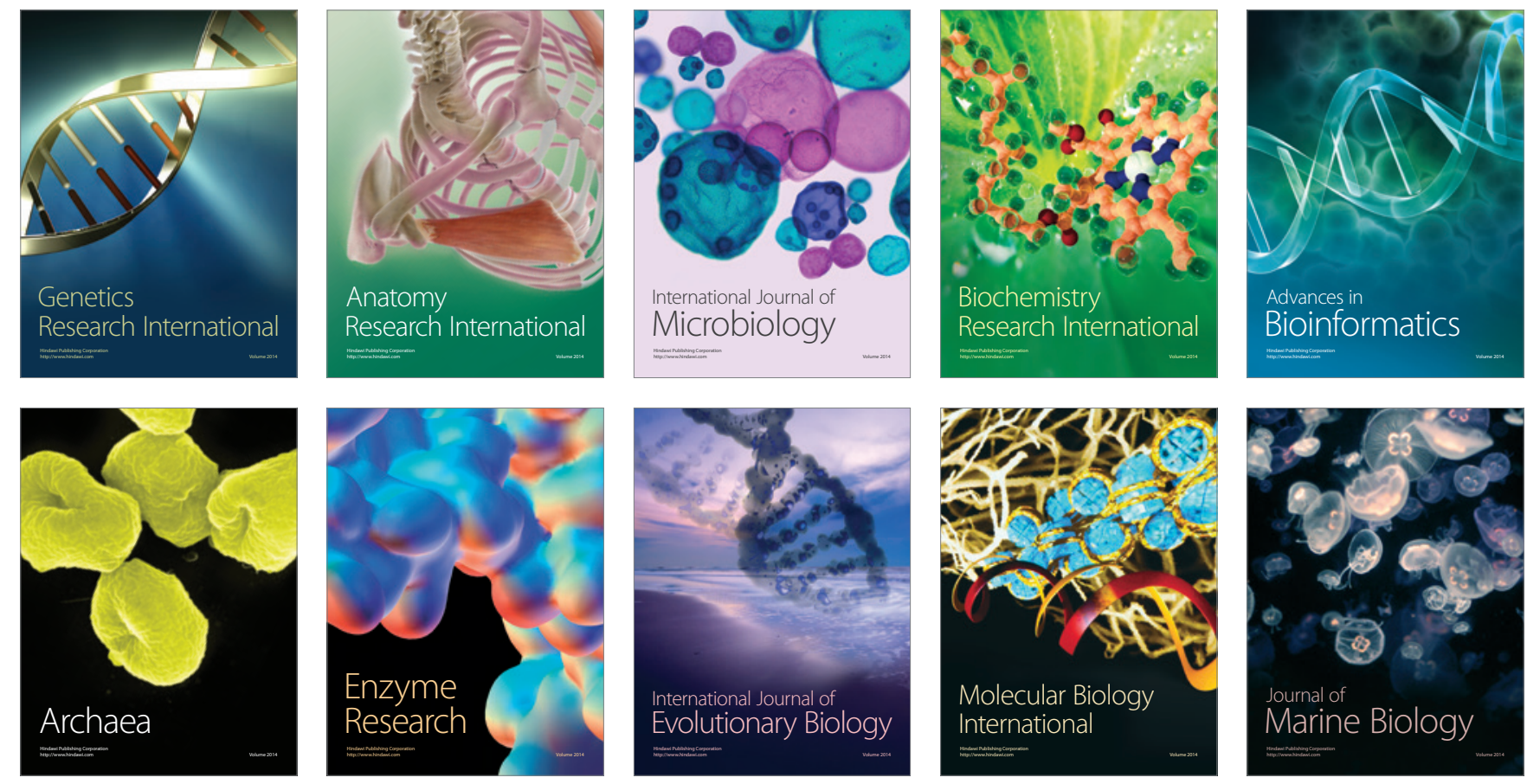